\title{
Profil protein lambung tikus model ulkus peptikum hasil induksi aspirin dengan terapi ekstrak daun katuk (Sauropus androgynus)
}

\author{
Janice Enola ${ }^{1}$, Sasangka Prasetyawan ${ }^{2}$, Dian Vidiastuti $^{3, *}$ \\ ${ }^{1}$ Program Studi Pendidikan Dokter Hewan, Fakultas Kedokteran Hewan, Universitas Brawijaya, Malang \\ ${ }^{2}$ Laboratorium Biokimia, Fakultas MIPA, Universitas Brawijaya, Malang \\ ${ }^{3}$ Bagian Klinik Veteriner, Fakultas Kedokteran Hewan, Universitas Brawijaya, Malang
}

\begin{abstract}
ABSTRAK: Ulkus peptikum dapat menyebabkan kerusakan jaringan yang menginduksi terjadinya perubahan profil protein berupa Heat Shock Proteins (HSPs). Penelitian ini memelajari efek antioksidan flavonoid daun katuk untuk pengobatan ulkus peptikum hasil induksi aspirin pada tikus. Tikus putih (Rattus norvegicus) sebanyak 20 ekor dibagi menjadi 5 kelompok perlakuan yaitu kontrol positif (ulkus peptikum), kontrol negatif, terapi P1 (8,1 mg/100 gram BB), terapi P2 (16,2 mg/100 gram BB), dan terapi P3 (24,3 mg/100 gram BB). Perlakuan diberikan selama 14 hari. Induksi ulkus peptikum dilakukan dengan pemberian aspirin $200 \mathrm{mg} / \mathrm{kg}$ BB selama 5 hari secara peroral. Isolasi protein lambung dan penentuan profil protein dilakukan dengan metode SDS-PAGE. Hasil penelitian menunjukkan bahwa protein yang muncul adalah HSP70, HSP60, HSP47, dan ubiquitin. HSP47dengan ukuran protein 47 kDa muncul pada kelompok P2 dan P3 sedemikian sehingga dapat diduga sebagai marker dalam proses kesembulan ulcer pada kasus ulkus peptikum.
\end{abstract}

Keywords:

pita protein, SDS PAGE, ulkus peptikum, daun katuk

\section{- PENDAHULUAN}

Ulkus peptikum adalah luka kecil pada mukosa esofagus, lambung dan duodenum (Torpy et al, 2012). Kejadian ulkus lambung pada hewan dilaporkan terjadi pada anjing (Parrah et al, 2013) dan kuda (Nieto, 2102). Produksi asam lambung berlebih menyebabkan inflamasi dan peningkatan Reactive Oxygen Species (ROS) penyebab kerusakan jaringan sehingga merubah profil protein berupa Heat Shock Proteins (HSPs). Protein tersebut memfasilitasi sintesis dan perbaikan protein sel (Fornai et al, 2011). Daun katuk memiliki flavonoid yang berpotensi sebagai antioksidan kuat dengan nilai $\mathrm{IC}_{50}$ 80,81 ppm (Zuhra dkk, 2008). Penelitian ini bertujuan memperlajari efek antioksidan flavonoid daun katuk untuk pengobatan ulkus peptikum.

\section{- BAHAN DAN METODE}

Hewan coba. Tikus putih (Rattus norvegicus) strain Wistar jantan, 150-200 g, umur 8-12 minggu, sebanyak 20 ekor dibagi dalam 5 kelompok yaitu kontrol negatif (K-), kontrol positif (induksi ulkus peptikum, $\mathrm{K}+$ ), $\mathrm{P} 1$ terapi ekstrak daun katuk (8,1 mg/100 gram BB), P2 (16,2 mg/100 gram BB) dan P3 (24,3 mg/100 gram BB) sekali sehari selama 14 hari. Induksi ulkus peptikum dengan aspirin $200 \mathrm{mg} / \mathrm{kg} \mathrm{BB}$ selama 5 hari secara peroral (Acarturk et al, 2014). Daun katuk diekstrak dengan pelarut etanol.

Penentuan profil protein metode SDS-PAGE. Hewan coba dieuthanasi secara dislokasi leher. Lambung diambil dan dicuci dalam $\mathrm{NaCl}$ fisiologis $0,9 \%$, lalu dimasukkan
PBS-azida pH 7,4. Lambung ditimbang 0,50 mg, ditambah 1 mL larutan PBS-Tween : PMSF (9:1), dan sedikit pasir kuarsa lalu digerus dengan mortar yang diletakkan di atas balok es. Homogenat ditambah $2 \mathrm{~mL}$ larutan PBS-Tween : PMSF dalam mikrotube untuk dihomogenkan dan disentrifus 15 menit (6000 rpm). Supernatan diambil, dimasukkan mikrotube dan ditambah etanol absolut dingin 1:1 dan biarkan semalam. Sentrifugasi campuran pada $10.000 \mathrm{rpm} 15$ menit. Endapan dikeringkan dan ditambah larutan 0,02 M Tris- $\mathrm{HCl} \mathrm{pH}$ 6,5 dingin perbandingan 1:1.

Persiapan gel. Plat gel dibuat dua lapis yaitu gel sebagai tempat sampel (Stacking gel) dan sebagai media untuk pemisahan protein (Separating gel). Separating gel dituangkan dalam cetakan. Berikutnya Stacking gel dituang di atas separating gel yang telah memadat dan dipasang sisir hingga terbentuk sumuran gel.

Running sampel. Ekstrak kasar isolasi lambung $150 \mu \mathrm{l}$, ditambahkan $150 \mu \mathrm{l}$ Reducing Sampel Buffer (RSB), dan dipanaskan pada $100{ }^{\circ} \mathrm{C}$ (5 menit). Setelah dingin, $20 \mu \mathrm{l}$ sampel dimasukkan sumuran, salah satu sumuran gel diisi protein standar marker. Perwarnaan dengan merendam gel dalam larutan staining (30-60 menit). Warna latar dihilangkan dengan merendam gel dalam larutan destaining.

Diterima: 08-11-2017 | Direvisi: 10-12-2017 | Disetujui: 09-01-2018 () 2018 CC-BY-SA. Ini adalah artikel Open Access yang didistribusikan berdasarkan ketentuan dari Creative Commons Attribution ShareAlike 4.0 International License (https://creativecommons.org/licenses/by-sa/4.0/). 
Penentuan berat molekul (BM). Penentuan BM dilakukan dengan menghitung nilai Rf (Retardation factor). Kurva standar dibuat dengan $\mathrm{Rf}$ sebagai sumbu $\mathrm{X}$ dan logaritma berat molekul sebagi sumbu Y.

\section{- HASIL DAN PEMBAHASAN}

Protein 72 kDa (HSP70) terekspresi pada kelompok K+, P1, P2 dan P3. HSP70 muncul pada sel yang stres (Stetler et al, 2010). HSP70 berperan dalam sistem pertahanan mukosa lambung dari kematian sel oleh Tumor Necrosis Factor Alpha (TNF- $\alpha$ ) dan terekspresi akibat radikal bebas (Tsukimi and Okabe, 2001; Burkat et al, 2000). Protein 62 $\mathrm{kDa}$ (HSP60) muncul pada semua perlakuan. HSP60 merupakan protein mitokondria sel eukariot untuk regulasi pelipatan protein, apoptosis, interaksi molekul, dan normal pada sel lambung (Cappello et al, 2008). Protein $47 \mathrm{kDa}$ (HSP47) muncul pada kelompok P2 dan P3 (Gambar 1) dan diduga sebagai marker proses kesembulan ulkus peptikum.

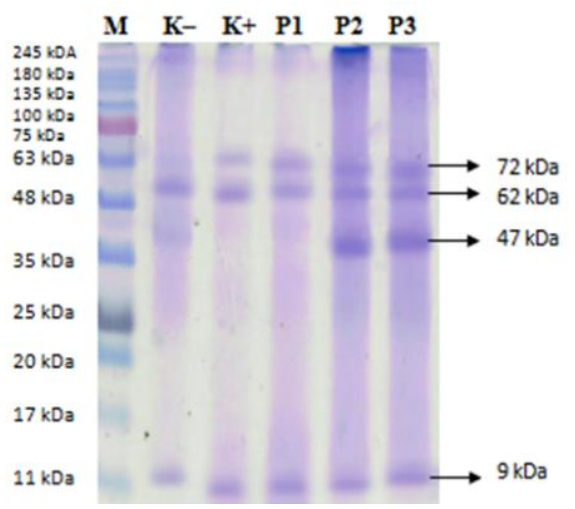

Gambar 1. Ekspresi protein lambung tikus model ulkus peptikum dengan metode SDS PAGE dengan berat molekul $72 \mathrm{kDa}, 62 \mathrm{kDa}, 47$ kDa dan 9 kDa. M:marker, K-:kontrol negatif, $\mathrm{K}+$ :kontrol positif, P1:perlakuan 1, P2:perlakuan 2, P3:perlakuan 3

HSP47 berperan spesifik dalam biosintesis kolagen pada proses kesembuhan luka (Ishida and Nagata, 2011). Pembentukan kolagen adalah tahap penting dalam pembentukan jaringan granulasi, sehingga terekspresi pada sel yang mengalami perbaikan (Tsukimi and Okabe, 2001). Daun katuk (Sauropus androgynus) mengandung flavonoid yang berfungsi sebagai antioksidan. Antioksidan menangkap radikal bebas (gugus hidroksil) pada kerusakan lambung akibat induksi aspirin. Gugus hidroksil senyawa flavonoid memberikan atom hidrogen kepada radikal bebas sehingga menjadi stabil dan proses kerusakan lipid lambung terhenti (Treml and Smejkal, 2016). Gugus hidroksil yang stabil menghambat aktivasi Nuclear Factor kappa B (NF$\mathrm{kB}$ ) yaitu faktor transkripsi dari sitokin pro-inflamasi seperti TNF- $\alpha$, sehingga pelepasan TNF- $\alpha$ berkurang (Fornai et al., 2011). Protein $9 \mathrm{kDa}$ (ubiquitin) terekspresi pada semua perlakuan yang secara normal terdapat pada sitoplasma semua sel eukariotik (Chiechanover, 1994). Fungsi utama ubiquitin dalam regulasi protein adalah degradasi protein dengan kompleks multienzimatik pada kasus kesalahan pelipatan protein, kerusakan atau malfungsi protein (Herrmann et al, 2007)

\section{- SIMPULAN}

Terapi ekstrak daun katuk (Sauropus androgynus) dosis $16,2 \mathrm{mg} / 100$ gram BB dan 24,3 mg/100 gram mampu menginduksi ekspresi protein marker kesembuhan ulkus dengan berat molekul $47 \mathrm{kDa}$.

\section{- INFORMASI PENULIS}

Penulis untuk Korespondensi

* DV: dianvidiastuti@gmail.com.

Fakultas Kedokteran Hewan, Universitas Brawijaya. Jalan MT Haryono, Kota Malang, Jawa Timur.

\section{- UCAPAN TERIMA KASIH}

Klinik Hewan, Fakultas Kedokteran Hewan Universitas Brawijaya atas bantuan pendanaan publikasi artikel

\section{- PUSTAKA ACUAN}

Acarturk G, Senol A, Akin M, Sutcu R, Sahin O, Isler M. 2014. The protective effects of kefir in aspirin induced gastric mucosal damage: an experimental study. Acta Medica Mediterranea. 30(4): 875-879.

Burkart V, H. Liu, K. Bellmann, D. Wissing, M. Jaattela, M. Cavallo. 2000. Natural resistance of human beta cells toward nitric oxide is mediated by heat shock protein 70 . J Biol Chem 27 5:19521-528.

Cappello F, Everly C, Lorenzo M, Giovanni Z, and Alberto J. 2008. Hsp60 expression, new locations, functions, and perspectives for cancer diagnosis and therapy. Journal Cancer Biology and Therapy, 1555-8576.

Ciechanover A. 1994. The ubiquitine proteasome proteolytic pathway. Cell. 79:13-21

Fornai M, Antonioli L, Colucci R, Tuccori M, Blandizzi C. 2011. Pathophysiology of gastric ulcer development and healing: molecular mechanisms and novel therapeutic options. In Peptic Ulcer Disease. InTech.

Herrmann J, Lilach O, and Amir L. 2007. Ubiquitin and UbiquitinLike Proteins in Protein Regulation. Ahajournals; 100:12761291.

Ishida Y, Nagata K. 2011. 9 Hsp47 as a collagen-specific molecular chaperone. Methods in enzymology. 499:167.

Nieto J. 2012. Diagnosing and treating gastric ulcers in horse. Center for equine health-the horses report.http://vetmeducdavis.edu

Parrah JD, Moulvi BA, Gazi MA, Makhdoomi DM, Athar H, Dar S, Mir AQ. 2013. Gastric ulceration in dog: a review. Vet world. 6(7): 449-454

Stetler RA, Gan Y, Zhang W, Liou AK, Gao Y, Cao G, Chen J. 2010. Heat shock proteins: cellular and molecular mechanism in the CNS. Progress in neurobiology. 92(2): 184-211.

Torpy JM, Lynm C, Golub RM. 2012. Peptic ulcer disease. JAMA. 307(12):1329

Tsukimi Y, Okabe S. 2001. Recent advances in gastrointestinal pathophysiology: role of heat shock proteins in mucosal defense and ulcer healing. Biological and Pharmaceutical Bulletin. 24(1):1-9.

Zuhra CF, Tarigan JB, Sihotang H. 2008. Aktivitas Antioksidan Senyawa Flavonoid dari Daun Katuk (Sauropus androgynus (L) Merr). Jurnal Biologi Sumatera. 3(1): 7-10. 